\title{
Studi Analisa Kalman Filter sebagai State Estimator untuk Meningkatkan Akurasi Pengukuran Kecepatan Motor DC
}

\author{
Ivan Sutresno Hadi Sujoto ${ }^{\text {a }}$, Hari Sutiksno ${ }^{a}$ \\ ${ }^{a}$ Departemen Teknik Elektro, Institut Sains dan Teknologi Terpadu Surabaya \\ E-mail: ivan.xiao.nexus@gmail.com
}

\begin{abstract}
Abstrak-State estimator merupakan sebuah teknik yang dipergunakan untuk mengestimasi besarnya nilai dari suatu sinyal yang telah tercampur dengan noise. Noise tersebut dapat terjadi pada proses di dalam suatu plant (motor DC) maupun pada pembacaan oleh sensor, yang menyebabkan nilai yang sesungguhnya dari suatu sinyal tidak dapat diketahui dengan akurat. Sinyal yang tercampur dengan noise tersebut dapat direduksi dengan berbagai cara, di antaranya adalah dengan menggunakan Kalman Filter. Kalman Filter merupakan sebuah state estimator dan merupakan filter linier terbaik (bila semua syarat terpenuhi) yang menggunakan konsep Minimum Mean Square Error (MMSE). Dalam penelitian ini akan diuji coba dan diamati manfaat Kalman Filter untuk mengestimasi nilai kecepatan sebuah motor DC yang sesungguhnya bila motor DC tersebut bekerja pada kondisi yang bernoise. Dalam penelitian ini akan diuji coba juga teknik pemfilteran data yang lain untuk dibandingkan performansinya terhadap Kalman filter. Pengujian dilakukan dengan menggunakan program simulasi dengan cara memberikan noise ke dalam sistem. Hasil uji coba menunjukkan bahwa Kalman Filter mampu mereduksi error hingga kurang dari $0.5 \mathrm{rad} / \mathrm{sec}$ hanya dalam waktu 0.025 detik.
\end{abstract}

Kata Kunci- Kalman Filter, Noise, State Estimator.

\section{LATAR BELAKANG}

$\mathrm{P}$ ada proses pengukuran, noise merupakan sebuah gangguan yang mengakibatkan pembacaan nilai suatu besaran menjadi bersifat random (acak). Akibat dari hal ini, maka pengukuran suatu nilai yang sesungguhnya, yang dihasilkan oleh sistem, tidak dapat diketahui secara akurat. Pentingnya sebuah akurasi pada proses pengukuran menginspirasi pemakaian teknik pemfilteran data, salah satunya adalah Kalman Filter. Oleh karena itu pada penelitian ini akan di uji coba dan diamati manfaat Kalman Filter untuk mengetahui nilai yang sesungguhnya dari suatu sistem (motor DC), bila sistem tersebut bekerja pada kondisi yang bernoise.

\section{TEORi PENUNJANG}

Adapun teori penunjang yang dipakai dalam pembuatan penelitian ini adalah:

\section{A. Akurasi}

Dalam bidang pengukuran, akurasi merupakan tingkat kedekatan pengukuran kuantitas terhadap nilai yang sebenarnya [14]. Oleh karenanya, pada suatu pengukuran yang akurat, jika didapatkan sekumpulan data dari hasil pengukuran yang berulang, maka akan didapatkan data yang rata-ratanya mendekati nilai yang sebenarnya. Pada proses pengukuran, umumnya akurasi dinyatakan dalam bentuk nilai error, yang merupakan selisih antara nilai yang sebenarnya dengan nilai yang didapat melalui proses pengukuran. Semakin kecil nilai error yang didapat, maka semakin akurat sebuah sistem.

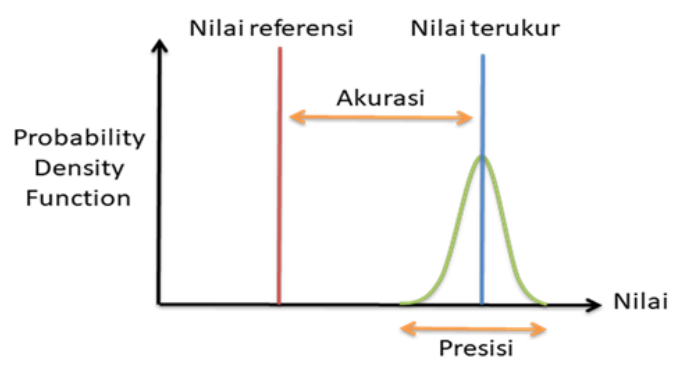

Gambar. 1. Akurasi dan presisi

Berbeda dengan akurasi, presisi merupakan kesalahan acak atau ukuran variabilitas dari suatu data. Secara singkat presisi menyatakan sejauh mana suatu pengukuran berulang menunjukkan hasil yang sama dalam kondisi yang sama [14].

Pada gambar 2 diilustrasikan sebuah target panah untuk memberikan gambaran perbedaan antara akurasi dan presisi. Gambar kiri menggambarkan tingkat akurasi yang tinggi tetapi presisi rendah, sedangkan gambar kanan menggambarkan tingkat akurasi yang rendah tetapi presisi tinggi. 

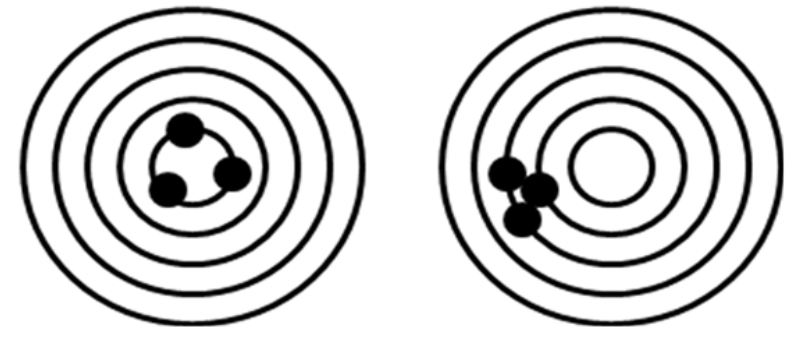

Gambar. 2. Ilustrasi akurasi dan presisi

\section{B. Gaussian White Noise}

Noise merupakan sebuah gangguan yang terjadi terhadap suatu sistem, baik yang disebabkan dari dalam sistem maupun dari luar sistem. Noise tersebut dapat berupa sebuah error (kesalahan) atau sinyal random yang membawa suatu informasi tidak berguna. Akibat adanya noise ini, maka hasil pengukuran tidak dapat diketahui secara akurat. Pada sistem yang akan dibahas untuk penelitian ini, noise dapat terjadi dari dalam suatu plant (motor DC), maupun ketidakakuratan pembacaan oleh sensor.

Salah satu kasus penting dari suatu sinyal random adalah keadaan dimana fungsi autokorelasinya berupa fungsi Dirac Delta $\delta(\tau)$, dimana memiliki nilai nol kecuali pada saat $\tau=0$.

$$
R_{w n}(\tau)=A \delta(\tau)
$$

Pada kasus ini, fungsi autokorelasinya akan berbentuk seperti spike (loncatan), dan transformasi fouriernya akan menghasilkan Power Spectral Density (kerapatan spektrum daya) yang konstan seperti yang ditunjukkan pada gambar 3 . Secara singkat, persamaan Power Spectral Densitynya dapat ditulis sebagai berikut:

$$
S_{w n}(j \omega)=A
$$
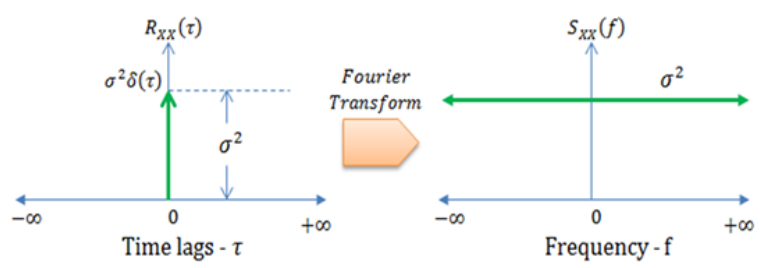

Gambar. 3. White Noise pada domain waktu (kiri) dan frekuensi (kanan)

Besarnya A merupakan varian dari suatu sinyal random. Inilah yang mendeskripsikan White Noise, dimana noise tersebut memiliki Power Spectral Density yang konstan pada seluruh frekuensi yang ada, dan setiap saat tidak berkorelasi dengan dirinya sendiri. Hal ini menunjukkan, bahwa White Noise merupakan sinyal yang terjadi secara random. Hal ini dapat pula diartikan, bahwa besarnya nilai dari suatu White Noise tidak dapat diprediksi, walaupun diketahui besarnya nilai dari suatu White Noise untuk saat ini.

Gaussian White Noise adalah White Noise yang terdistribusi secara Gaussian. Oleh karenanya, Gaussian White Noise memiliki zero mean (besarnya rata-rata adalah nol). Dalam hubungannya dengan Kalman Filter, akan diasumsikan bahwa sinyal noise yang terjadi pada sistem adalah Gaussian White Noise.

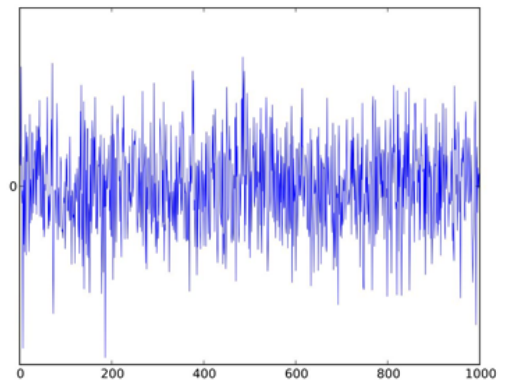

Gambar. 4. Sinyal Gaussian White Noise dengan zero mean

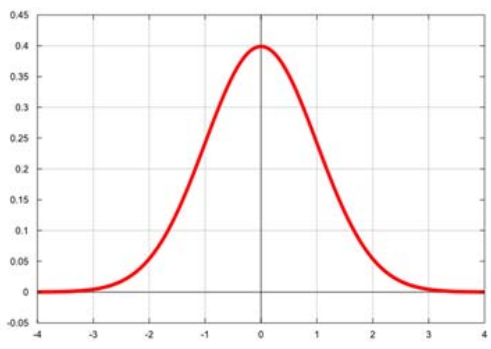

Gambar. 5. Kurva Gaussian terdistribusi normal

\section{State Space}

State Space adalah sebuah model matematika dari sebuah sistem sebenarnya yang terdiri atas beberapa input dan output (MIMO: Multiple Input Multiple Output), serta variabel state yang digambarkan dalam bentuk persamaan differensial. Berikut adalah bentuk persamaan secara umum dari sebuah State Space:

$$
\begin{aligned}
& \dot{x}=A x+B u \\
& y=C x+D u
\end{aligned}
$$

Dalam penelitian ini, penggunaan dari State Space adalah untuk menggambarkan model sebenarnya dari sebuah motor DC secara matematika. Selain itu pula, untuk menggunakan Kalman Filter, maka sebuah sistem harus dapat direpresentasikan ke dalam model State Space.

\section{Moving Average Filter}

Suatu teknik yang dipergunakan untuk mereduksi noise disebut dengan filter. Salah satu contoh sederhana dari teknik pemfilteran data adalah Moving Average Filter.

Moving Average Filter (Rolling Average Filter, Running Average Filter) adalah suatu teknik pemfilteran untuk menganalisa point data dengan membuat serangkaian ratarata dari data tersebut. Berikut adalah persamaan sederhana dari teknik Moving Average Filter:

$\bar{x}_{k}=\frac{k-1}{k} \bar{x}_{k-1}+\frac{1}{k} x_{k}$

\section{E. Kalman Filter}

Kalman Filter merupakan sebuah state estimator yang berdasarkan konsep estimasi optimal dengan cara mereduksi error varian (Minimum Mean Square Error). Dalam hal ini, penggunaan Kalman Filter adalah untuk menyelesaikan permasalahan estimasi varian minimum untuk suatu sistem linier, dimana terdapat gangguan berupa noise, yang dapat 
mempengaruhi keadaan state [11].

Secara singkat, Kalman Filter merupakan suatu algoritma matematika yang menggunakan sekumpulan data, yang diamati dari waktu ke waktu, dimana data-data tersebut mengandung noise dan ketidakakuratan lainnya, dan mampu menghasilkan estimasi state yang lebih akurat dari pada berdasarkan data yang diperoleh melalui pengukuran tunggal saja.

Metode ini dinamakan dari seorang ahli teknik elektro dan juga matematika bernama Rudolph Emil Kalman. Metode ini dipublikasikan pertama kali pada salah satu jurnal yang cukup terkenal pada tahun 1960 yang membahas tentang sebuah solusi rekursif untuk masalah pemfilteran data linier yang tidak kontinu.

Kalman Filter merupakan state estimator yang menggunakan teknik "Prediksi" dan "Koreksi". Dua tahap ini akan dilakukan secara rekursiv dan saling berhubungan satu sama lain.

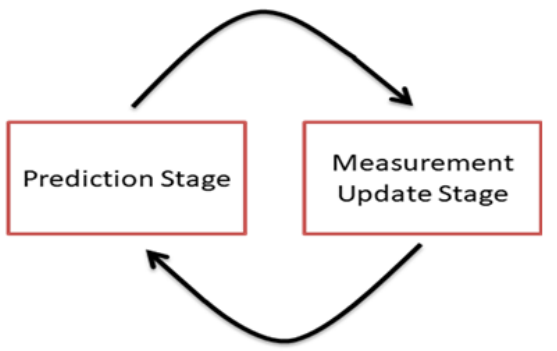

Gambar. 6. Tahap prediksi dan koreksi pada Kalman Filter

Pada tahap prediksi akan dilakukan 2 proses utama, yaitu prediksi vektor state dan matrix kovarian. Berikut adalah 2 proses utama yang akan dilakukan pada tahap prediksi :

$\hat{x}_{k \mid k-1}=A \hat{x}_{k-1}+B u_{k}$

$P_{k \mid k-1}=A P_{k-1} A^{T}+Q$

dimana :

- $\hat{\mathrm{x}}_{\mathrm{k} \mathrm{k}-1} \quad$ : Predicted state vector

- $\hat{\mathrm{X}}_{\mathrm{k}-1} \quad$ : Previous state vector

- $\hat{\mathrm{P}}_{\mathrm{k} \mid \mathrm{k}-1} \quad$ : Predicted covariance matrix

- $\quad \mathrm{P}_{\mathrm{k}-1} \quad$ : Previous covariance matrix

- $\mathrm{u}_{\mathrm{k}} \quad$ : Control variable vector

- A : Transition matrix

- Q : Process covariance matrix

Pada tahap koreksi akan didapatkan hasil pengukuran (contoh : melalui sensor), dan kemudian digabungkan hasil pengukuran tersebut dengan hasil yang didapat pada tahap prediksi untuk mendapatkan hasil estimasi yang lebih baik. Pada tahap prediksi terdapa 3 proses utama yaitu perhitungan Kalman Gain, proses update prediksi vektor state, dan proses update prediksi matrix kovarian. Berikut adalah 3 persamaan yang akan digunakan pada tahap koreksi :

$$
\begin{aligned}
& K=\left(P_{k \mid k-1} H^{T}\right)\left(H P_{k \mid k-1} H^{T}+R\right)^{-1} \\
& \hat{x}_{k}=\hat{x}_{k \mid k-1}+K\left(y_{k}-H \hat{x}_{k \mid k-1}\right)
\end{aligned}
$$

$$
P_{k}=(I-K H) P_{k \mid k-1}
$$

dimana :

- $\hat{\mathrm{x}}_{\mathrm{k}} \quad$ : State vector

- $\mathrm{P}_{\mathrm{k}} \quad$ : Covariance matrix

- $\mathrm{y}_{\mathrm{k}} \quad$ : Measurement of the state vector

- $\mathrm{K}$ : Kalman Gain

- $\mathrm{H}$ : Transformation matrix

- $\mathrm{R}$ : Measurement covariance matrix

- I : Matrix identitas

\section{F. Motor DC}

Motor DC adalah sebuah aktuator, yaitu sebuah alat yang mengubah energi listrik menjadi energi mekanik. Dalam penelitian ini, motor DC akan dipergunakan sebagai plant dari suatu sistem kontrol.

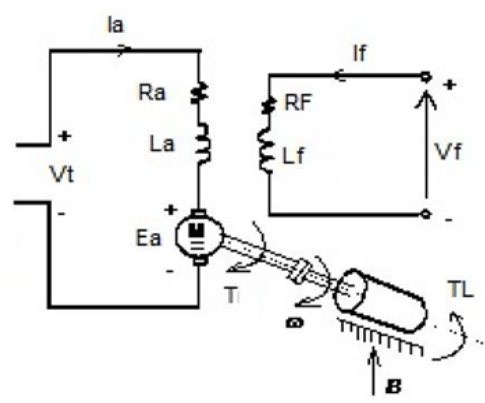

Gambar. 7. Rangkaian ekuivalen motor DC

Dalam hubungannya dengan noise, pada motor DC umumnya noise disebabkan oleh beberapa faktor, diantaranya adalah akibat adanya goncangan pada shaft (poros) motor, sehingga timbul spark (percikan bunga api) pada kontak antara komutator dan brush (sikat). Disamping itu juga, spark dapat muncul akibat pergerakan motor DC, yang menyebabkan perubahan arah arus pada kumparan motor. Sumber noise lainnya dalam sistem adalah pada sumber tenaga. Karena sumber tenaga memiliki hambatan dalam tidak sama dengan nol, maka arus motor yang tidak konstan, yang mengalir setiap periode rotasi, akan menyebabkan ripple (riak) pada terminal sumber tegangan [10].

Suatu motor DC dapat digambarkan secara matematika dalam bentuk model matematika elektronika dan mekanika. Berikut adalah model matematika elektronika motor DC :

$\frac{d I_{a}}{d t}=\frac{1}{L_{a}}\left(V_{t}-R_{a} I_{a}-K_{e} \omega\right)$

Untuk mendapatkan model matematika mekanika motor DC dapat dipergunakan persamaan berikut :

$\frac{d \omega}{d t}=\frac{1}{J}\left(K_{t} I_{a}-T_{L}-B \omega\right)$

\section{G. Diskritisasi Sistem Kontinu}

Dikarenakan penggunaan Kalman Filter diskrit, maka 
perlu dikonversikan State Space kontinu menjadi State Space diskrit. Berikut adalah persamaan yang dipergunakan untuk mendiskritkan matrix kontinu $\mathrm{Ac}, \mathrm{Bc}, \mathrm{Cc}$, dan $\mathrm{Dc}$ menjadi matrix diskrit $\mathrm{Ad}, \mathrm{Bd}, \mathrm{Cd}$, dan $\mathrm{Dd}$ :

$A_{d}=e^{A_{c} T}$

$B_{d}=A_{c}^{-1}\left(e^{A_{c} T}-I\right) B_{c}$

$C_{d}=C_{c}$

$D_{d}=D_{c}$

\section{PEREnCANAAN SimUlasi}

Perencanaan simulasi merupakan tahap-tahap yang perlu dilakukan sebelum melakukan proses simulasi. Tahapan tersebut meliputi penentuan spesifikasi sistem kontrol dan noise, pemodelan motor DC, dan mendesain filter.

\section{A. Spesifikasi Sistem Kontrol}

Berikut adalah spesifikasi motor DC yang akan dipergunakan untuk proses simulasi [2] :

- $\quad$ Daya output [P]

- Tegangan kerja [V]

$: 120 \mathrm{~V}$

- Kecepatan putar $[\omega]$

: $63 \mathrm{rad} / \mathrm{sec}$

- Resistansi jangkar $\left[\mathrm{R}_{\mathrm{a}}\right]$

$: 0.48 \Omega$

- Induktansi jangkar $\left[\mathrm{L}_{\mathrm{a}}\right]$

: $0.01 \mathrm{H}$

- Momen inersia rotor $[\mathrm{J}]$

$: 0.33 \mathrm{Kg} \cdot \mathrm{m}^{2}$

- Koefisien gesekan [B]

: 0.001 N.m.sec ${ }^{2}$

- Konstanta listrik motor $\left[\mathrm{K}_{\mathrm{e}}\right]$

$: 1.79 \mathrm{Nm} / \mathrm{A}$

- Konstanta torsi motor $\left[\mathrm{K}_{\mathrm{t}}\right]$

$: 1.79 \mathrm{NM} / \mathrm{a}$

Berdasarkan data tersebut, maka dapat diketahui besar torsi beban maksimum adalah sebesar $28.5 \mathrm{Nm}$ dengan menggunakan persamaan berikut :

$T_{L}=\frac{P[\mathrm{HP}] \times 746}{\omega[\mathrm{rpm}] \times \frac{2 \pi}{60}}$

\section{B. Model Motor DC}

Sebelum memulai proses simulasi, maka dibutuhkanlah sebuah model matematika dari sebuah motor DC. Dalam penelitian ini, akan terdapat 2 model dari sebuah motor DC, yaitu model diagram blok motor DC, dan model State Space motor DC.

Model diagram blok motor DC merupakan salah satu bentuk representasi matematika dari sebuah motor DC. Tujuan pembuatan model ini adalah sebagai model referensi dari sebuah motor DC, dimana output dari model ini bersifat ideal tanpa gangguan apapun (contoh : noise). Berdasarkan persamaan 11, 12, dan spesifikasi sistem kontrol, maka didapatkanlah model diagram blok motor DC sebagai berikut :

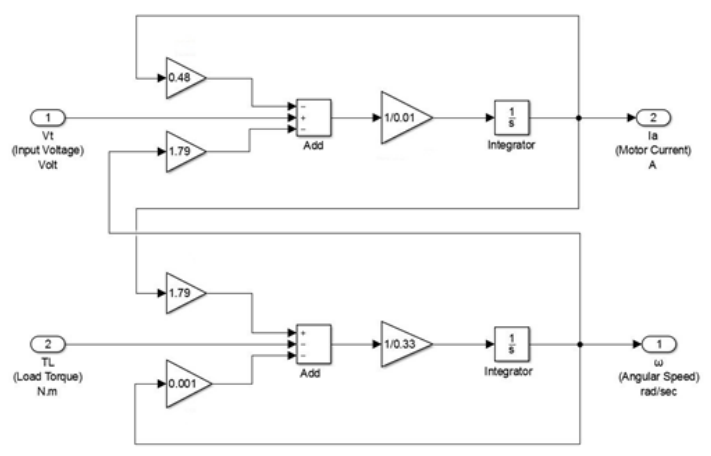

Gambar. 8. Model diagram blok motor DC

Agar tampilan model motor DC pada gambar 8 terlihat lebih sederhana, diagram blok tersebut dapat diubah dengan menjadikannya sebagai suatu subsistem.

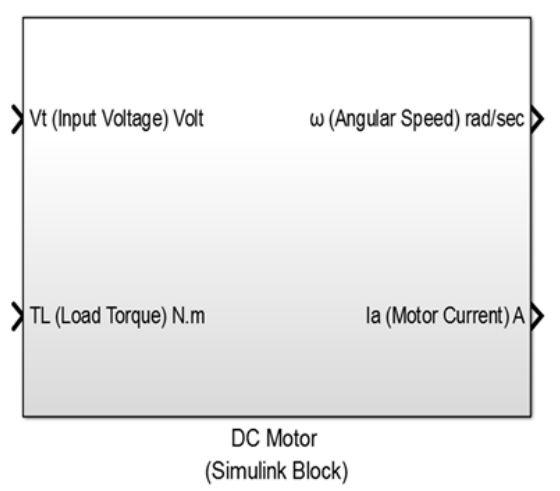

Gambar. 9. Subsistem model motor DC

Salah satu representasi lain dari model matematika sebuah motor DC adalah dengan menggunakan model State Space. Dalam penelitian ini diperlukan model State Space dari suatu motor DC dikarenakan untuk mengaplikasikan Kalman Filter, maka suatu sistem harus dapat direpresentasikan kedalam bentuk State Space. Berdasarkan persamaan 3 dan spesifikasi sistem kontrol, maka didapatkanlah model State Space motor DC sebagai berikut:

$\left[\begin{array}{c}\frac{d \omega}{d t} \\ \frac{d I_{a}}{d t}\end{array}\right]=\left[\begin{array}{cc}-0.0030 & 5.42 \\ -179 & -48\end{array}\right]\left[\begin{array}{l}\omega \\ I_{a}\end{array}\right]+\left[\begin{array}{cc}-3 & 0 \\ 0 & 100\end{array}\right]\left[\begin{array}{l}T_{L} \\ V_{t}\end{array}\right]$

Dimana besarnya matrix A dan B masing-masing adalah sebagai berikut :

$$
\begin{aligned}
& A=\left[\begin{array}{cc}
-0.0030 & 5.42 \\
-179 & -48
\end{array}\right] \\
& B=\left[\begin{array}{cc}
-3 & 0 \\
0 & 100
\end{array}\right]
\end{aligned}
$$

Berdasarkan persamaan 4, maka perlu ditentukan juga besarnya matrix $\mathrm{C}$ dan $\mathrm{D}$. Dalam hal ini, matrix $\mathrm{C}$ akan berfungsi sebagai matrix transformasi, sehingga didapatkanlah matrix $\mathrm{C}$ sebagai berikut : 
$C=\left[\begin{array}{ll}1 & 0 \\ 0 & 1\end{array}\right]$

Dikarenakan tidak adanya jaringan feedforward pada model motor DC, maka didapatkanlah matrix D sebagai berikut :

$D=\left[\begin{array}{ll}0 & 0 \\ 0 & 0\end{array}\right]$

Berikut adalah model State Space yang digambarkan pada program Matlab berdasarkan persamaan 19, 20, 21, dan 22 :

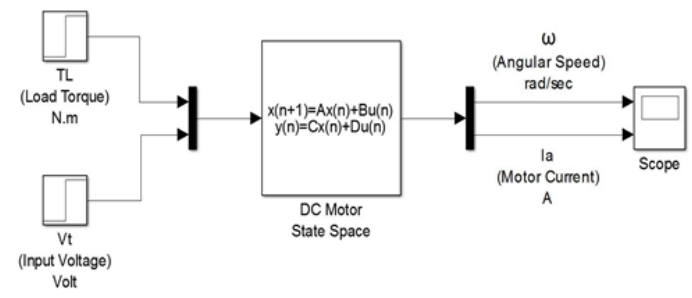

Gambar. 10. Model State Space motor DC

\section{Analisa Sumber Noise}

Berikut adalah spesifikasi noise yang akan dipergunakan untuk proses simulasi :

- Tipe Noise : Gaussian White Noise

- Varian : 1 (pada input)

9 (pada output)

Noise tersebut akan diproduksi oleh program Matlab dengan bantuan blok bernama Band-Limited White Noise.

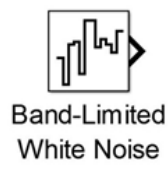

Gambar. 11. Blok Bandlimited White Noise

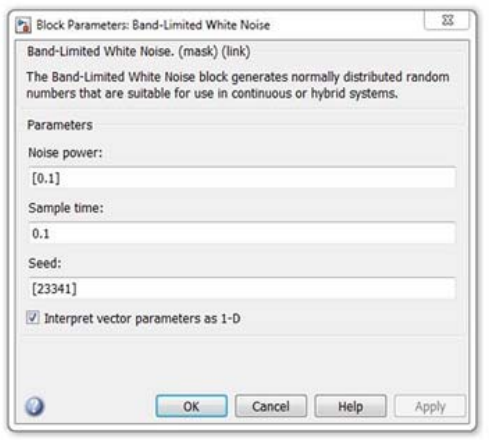

Gambar. 12. Tampilan editor parameter Bandlimited White Noise

Untuk mengetahui besarnya varian yang mampu dihasilkan oleh blok Bandlimited White Noise, maka dapat dipergunakan persamaan berikut :

$\sigma^{2}=\frac{\text { Noise Power }}{\text { Sample Time }}$
Berikut adalah contoh sinyal noise yang akan diberikan kepada sistem selama proses simulasi dengan sample time Ts $=0.001$ :

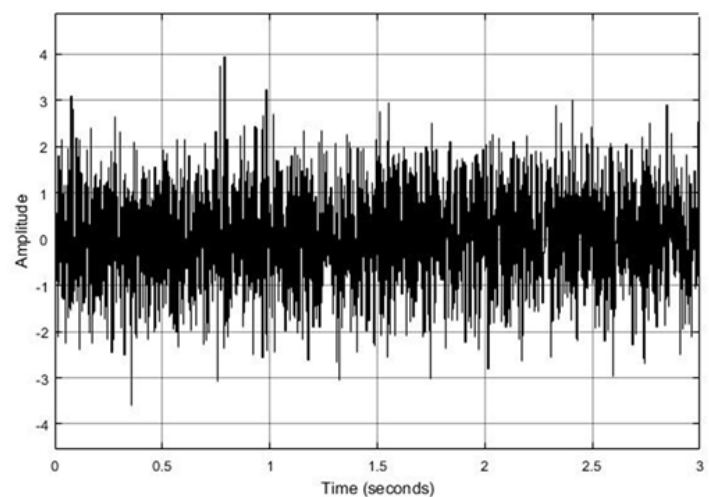

Gambar. 13. Noise pada proses dengan varian $=1$

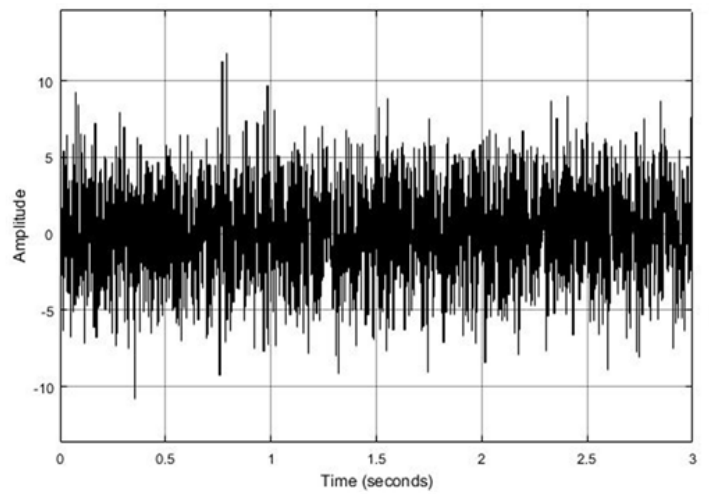

Gambar. 14. Noise pada proses dengan varian $=9$

\section{Desain Blok Moving Average Filter}

Untuk mendesain blok Moving Average Filter akan digunakan blok-blok dasar yang tersedia pada program Matlab. Beberapa contoh blok-blok dasar tersebut adalah blok Gain, blok Product, blok Divide, dan lain-lain.

Berdasarkan persamaan 5, maka dapat digambarkan blok Moving Average Filter sebagai berikut :

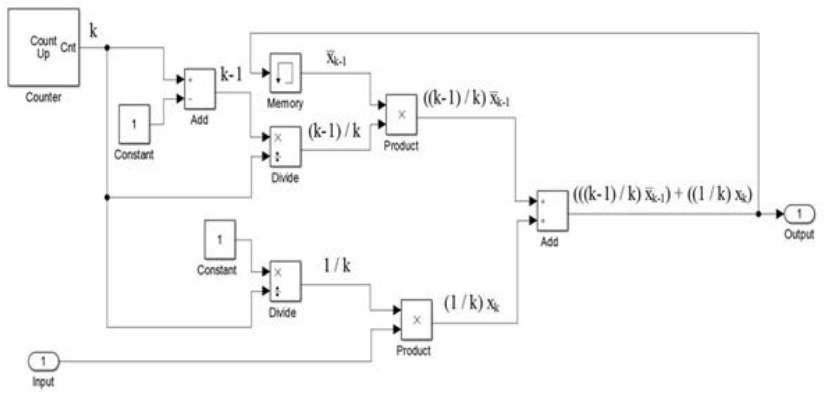

Gambar. 15. Blok Moving Average Filter

Untuk mempermudah desain, filter pada gambar 15 dapat dibuat menjadi subsistem sebagai berikut : 


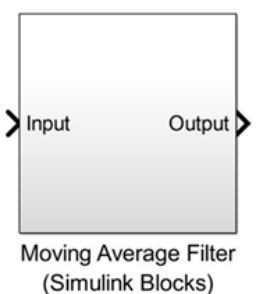

Gambar. 16. Subsistem blok Moving Average Filter

\section{E. Desain Blok Kalman Filter}

Dalam penelitian ini, akan didesain sebuah blok Kalman Filter untuk dipergunakan dalam proses simulasi menggunakan program Matlab. Proses desain blok Kalman Filter akan dilakukan dengan menggunakan blok-blok dasar yang tersedia pada program Matlab.

Berdasarkan persamaan $6,7,8$, 9, dan 10, maka dapat didesain sebuah blok Kalman Filter seperti yang ditunjukkan pada gambar 17:

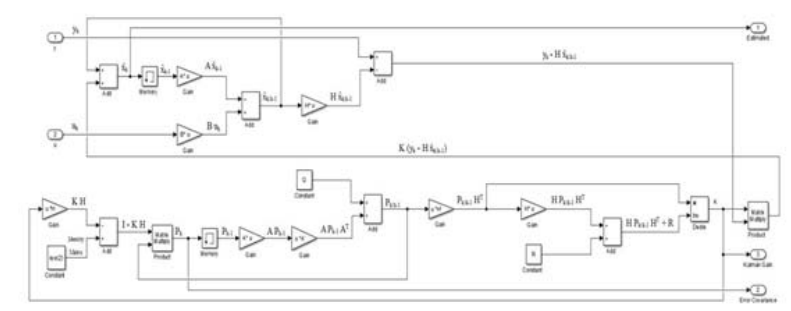

Gambar. 17. Blok Kalman Filter

Untuk mempermudah desain, blok Kalman Filter pada gambar 17 dapat dibuat menjadi subsistem sebagai berikut :

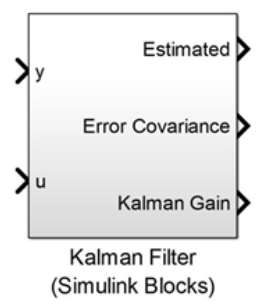

Gambar. 18. Subsistem blok Kalman Filter

\section{F. Diskritisasi Parameter State Space}

Berdasarkan persamaan 13 dan 19, maka didapatkanlah matrix A dalam bentuk diskrit :

$$
A_{d}=\left[\begin{array}{rr}
0.9995 & 0.0053 \\
-0.1747 & 0.9527
\end{array}\right]
$$

Begitu juga dengan bantuan persamaan 14 dan 20, maka didapatkanlah matrix $\mathrm{B}$ dalam bentuk diskrit :

$B_{d}=\left[\begin{array}{cc}-0.0030 & 0.0003 \\ 0.0003 & 0.0976\end{array}\right]$

Besarnya matrix $\mathrm{C}$ dan $\mathrm{D}$ dalam bentuk diskrit adalah sama dengan matrix $\mathrm{C}$ dan $\mathrm{D}$ dalam bentuk kontinu :

$$
\begin{aligned}
C_{d} & =\left[\begin{array}{ll}
1 & 0 \\
0 & 1
\end{array}\right] \\
D_{d} & =\left[\begin{array}{ll}
0 & 0 \\
0 & 0
\end{array}\right]
\end{aligned}
$$

\section{G. Parameter Simulasi Kalman Filter}

Sebelum dilakukan simulasi, perlu dicari terlebih dahulu parameter-parameter Kalman Filter, sehingga kinerja Kalman Filter menjadi lebih baik. Parameter-parameter Kalman Filter tersebut meliputi xo, Po, Q, dan R, dimana :

- $\mathrm{x}_{\mathrm{o}} \quad$ : Initial state

- $\mathrm{P}_{\mathrm{o}} \quad$ : Initial error covariance

Penentuan besarnya parameter-parameter tersebut akan dilakukan berdasarkan percobaan, dengan mengamati besarnya varian pada sistem (baik pada proses maupun pengukuran) setelah diberikan noise sesuai dengan spesifikasi noise. Berikut adalah parameter-parameter Kalman Filter yang akan dipergunakan selama proses simulasi :

$$
\begin{aligned}
& x_{0}=\left[\begin{array}{l}
0 \\
0
\end{array}\right] \\
& P_{0}=\left[\begin{array}{ll}
1 & 0 \\
0 & 1
\end{array}\right] \\
& Q=\left[\begin{array}{cc}
0.003241 & 0 \\
0 & 0.104
\end{array}\right] \\
& R=\left[\begin{array}{ll}
9 & 0 \\
0 & 1
\end{array}\right]
\end{aligned}
$$

\section{UJI COBA KALMAN FILTER DENGAN MATLAB}

Pada bab ini akan dibahas tentang pengamatan hasil simulasi penggunaan Kalman Filter untuk meingkatkan akurasi pengukuran kecepatan motor DC menggunakan program Matlab. Dalam simulasi akan dilakukan pengamatan terhadap tingkat keakurasian Kalman Filter dibandingkan dengan beberapa teknik pemfilteran data yang lain. Uji coba akan dilakukan pada motor DC dengan inputan berupa tegangan $\mathrm{Vt}$, dan torsi beban $\mathrm{TL}$, dimana terjadi sebuah noise pada tegangan Vt. Sementara itu, hasil output sistem berupa kecepatan putar $\omega$ yang mengandung noise akibat proses maupun pembacaan oleh sensor akan diamati. Pada uji coba ini akan diberikan noise yang sama sesuai dengan spesifikasi noise untuk setiap jenis filter yang akan di uji, dan untuk menunjukkan respon filter terhadap perubahan beban, maka pemberian torsi beban TL akan dilakukan tanpa beban $(\mathrm{TL}=0 \mathrm{Nm})$, dan dengan perubahan beban dari tanpa beban menuju ke beban penuh $(\mathrm{TL}=28.5$ $\mathrm{Nm})$ secara tiba-tiba.

Berdasarkan persamaan 30, dikarenakan besarnya varian noise pada proses sangatlah kecil $(0.003241 \mathrm{rad} / \mathrm{sec})$, maka besarnya noise pada proses dapat diabaikan. Oleh karenanya untuk mempermudah proses simulasi, besarnya nilai kecepatan putar yang sebenarnya dari sistem akan dianggap mendekati kecepatan putar sistem dalam keadaan ideal tanpa 
Sujoto, dkk. : Studi Analisa Kalman Filter sebagai State Estimator untuk Meningkatkan Akurasi Pengukuran Kecepatan Motor DC

TABEL I

noise. Untuk itu selama proses uji coba simulasi akan diambil kecepatan motor DC pada keadaan ideal sebagai referensi nilai kecepatan yang sebenarnya, yang dihasilkan oleh sistem.

Gambar 19 adalah blok uji coba Matlab dari sistem kontrol kecepatan motor DC.

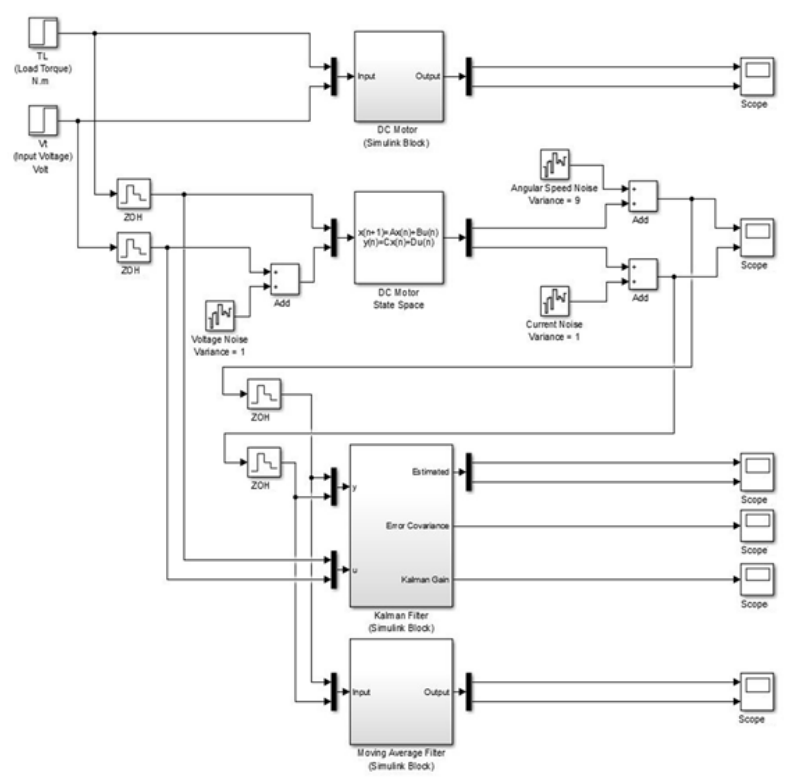

Gambar. 19. Blok uji coba

\section{A. Uji Coba Moving Average Filter}

Untuk melakukan uji coba terhadap teknik Moving Average Filter tanpa beban dapat dilakukan dengan memberikan input berupa tegangan $\mathrm{Vt}=120 \mathrm{~V}$ dan torsi beban $\mathrm{TL}=0 \mathrm{Nm}$. Pada gambar 20 ditunjukkan hasil simulasi terhadap teknik Moving Average Filter tanpa pemberian beban dengan tTotal $=10$ detik.

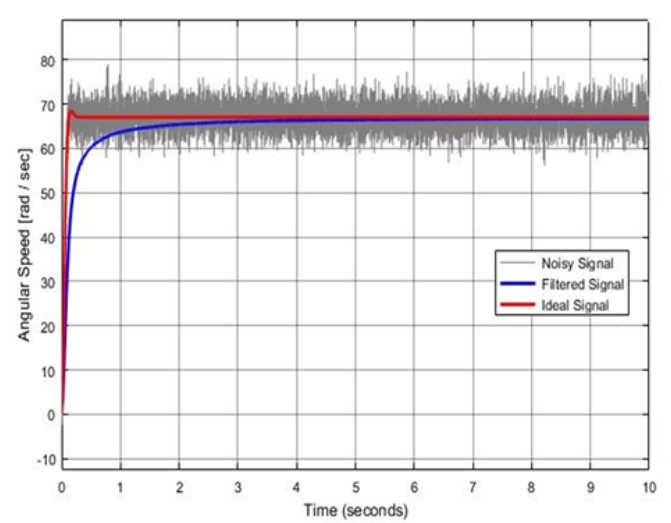

Gambar. 20. Grafik uji coba Moving Average Filter tanpa beban

Pada gambar 20 ditunjukkan 3 buah grafik, dimana warna abu-abu menyatakan noise, warna merah adalah nilai kecepatan putar yang ideal, dan warna biru adalah hasil sinyal yang telah difilter menggunakan teknik Moving Average Filter. Pada tabel I ditunjukkan hasil pengamatan tingkat keakurasian pada beberapa sampel pembacaan kecepatan motor DC berdasarkan gambar 20.

\begin{tabular}{|c|c|c|c|c|}
\hline $\begin{array}{l}\text { Waktu } \\
\text { [detik] }\end{array}$ & $\begin{array}{c}\text { Sinyal } \\
\text { Ideal } \\
\text { [rad/sec] }\end{array}$ & $\begin{array}{c}\text { Sinyal } \\
\text { Noise } \\
{[\mathrm{rad} / \mathrm{sec}]}\end{array}$ & $\begin{array}{c}\text { Moving } \\
\text { Average } \\
\text { Filter } \\
\text { [rad/sec] }\end{array}$ & $\begin{array}{c}\text { Error } \\
{[\mathbf{r a d} / \mathrm{sec}]}\end{array}$ \\
\hline 0.001 & 0.03 & 7.19 & 4.13 & 4.1 \\
\hline 0.050 & 35.58 & 30.67 & 14.87 & 20.71 \\
\hline 0.100 & 62.78 & 69.34 & 33.40 & 29.38 \\
\hline 0.500 & 67.03 & 70.73 & 60.18 & 6.85 \\
\hline 1.000 & 67.03 & 68.78 & 63.65 & 3.38 \\
\hline 2.000 & 67.03 & 66.06 & 65.38 & 1.65 \\
\hline 4.000 & 67.03 & 67.60 & 66.28 & 0.75 \\
\hline 6.000 & 67.03 & 70.47 & 66.53 & 0.50 \\
\hline 8.000 & 67.03 & 62.25 & 66.66 & 0.37 \\
\hline 10.000 & 67.03 & 68.54 & 66.71 & 0.32 \\
\hline
\end{tabular}

Pada gambar 21 ditunjukkan tingkat keakurasian teknik Moving Average Filter terhadap waktu tanpa beban berdasarkan tabel I.

Untuk mendapatkan respon dari teknik Moving Average Filter dengan perubahan beban dari $\mathrm{TL}=0 \mathrm{Nm}$ ke $\mathrm{TL}=$ 28.5 Nm secara tiba-tiba dapat dilakukan dengan memberikan input berupa tegangan $\mathrm{Vt}=120 \mathrm{~V}$ dan torsi beban yang ingin disimulasikan ke dalam Plant. Gambar 22 adalah respon kecepatan motor DC dengan menggunakan teknik Moving Average Filter akibat terjadinya perubahan beban pada saat $\mathrm{t}=3$ detik dengan $\mathrm{tTotal}=15$ detik.

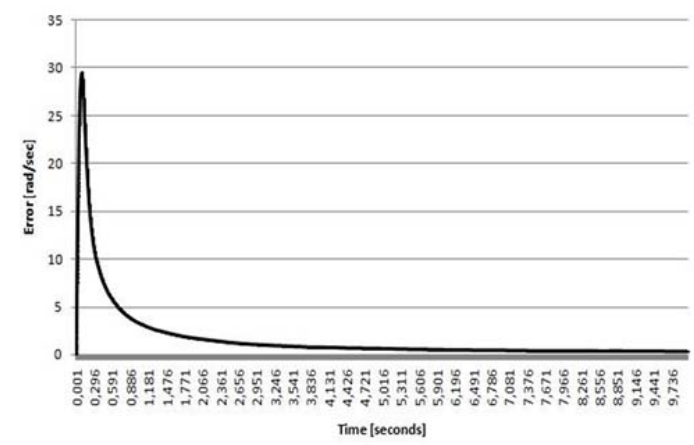

Gambar. 21. Grafik akurasi Moving Average Filter terhadap waktu tanpa beban

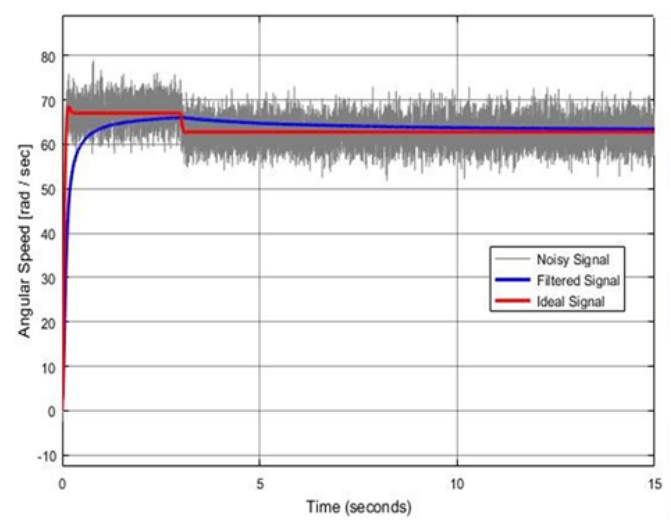

Gambar. 22. Grafik uji coba Moving Average Filter dengan perubahan beban

Pada gambar 22 ditunjukkan 3 buah grafik, dimana warna abu-abu menyatakan noise, warna merah adalah nilai kecepatan putar yang ideal, dan warna biru adalah hasil sinyal yang telah difilter menggunakan teknik Moving 
Average Filter. Pada tabel II ditunjukkan hasil pengamatan tingkat keakurasian pada beberapa sampel pembacaan kecepatan motor DC berdasarkan gambar 22.

TABEL II

Hasil Pengamatan Moving Average Filter dengan Perubahan BEBAN

\begin{tabular}{cccccc}
\hline \hline No & $\begin{array}{c}\text { Waktu } \\
{[\text { detik] }}\end{array}$ & $\begin{array}{c}\text { Sinyal } \\
\text { Ideal } \\
{[\mathbf{r a d} / \mathbf{s e c}]}\end{array}$ & $\begin{array}{c}\text { Sinyal } \\
\text { Noise } \\
{[\mathbf{r a d} / \mathbf{s e c}]}\end{array}$ & $\begin{array}{c}\text { Moving } \\
\text { Average } \\
\text { Filter } \\
{[\mathbf{r a d} / \mathbf{s e c}]}\end{array}$ & $\begin{array}{c}\text { Error } \\
{[\mathbf{r a d} / \mathbf{s e c}]}\end{array}$ \\
\hline 1 & 2.000 & 67.03 & 66.06 & 65.38 & 1.65 \\
2 & 3.000 & 67.03 & 74.35 & 66.02 & 1.01 \\
3 & 3.050 & 63.67 & 64.99 & 65.99 & 2.32 \\
4 & 3.100 & 62.67 & 64.51 & 65.95 & 3.28 \\
5 & 5.000 & 62.76 & 62.35 & 64.73 & 1.97 \\
6 & 7.000 & 62.76 & 67.22 & 64.18 & 1.42 \\
7 & 9.000 & 62.76 & 66.58 & 63.84 & 1.08 \\
8 & 11,000 & 62.76 & 59.09 & 63.63 & 0.87 \\
9 & 13.000 & 62.76 & 63.34 & 63.51 & 0.75 \\
10 & 15.000 & 62.76 & 68.68 & 63.42 & 0.66 \\
\hline \hline
\end{tabular}

Pada gambar 23 ditunjukkan tingkat keakurasian teknik Moving Average Filter terhadap waktu dengan perubahan beban berdasarkan tabel II.

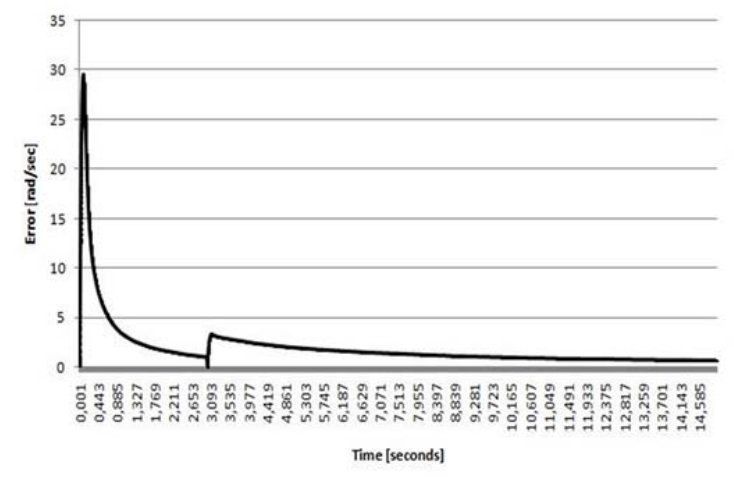

Gambar. 23. Grafik akurasi Moving Average Filter terhadap waktu dengan perubahan beban

\section{B. Uji Coba Kalman Filter}

Untuk melakukan uji coba terhadap teknik Kalman Filter tanpa beban dapat dilakukan dengan memberikan input berupa tegangan $\mathrm{Vt}=120 \mathrm{~V}$ dan torsi beban $\mathrm{TL}=0 \mathrm{Nm}$. Pada gambar 24 ditunjukkan hasil simulasi terhadap teknik Kalman Filter tanpa pemberian beban dengan tTotal $=0.5$ detik.

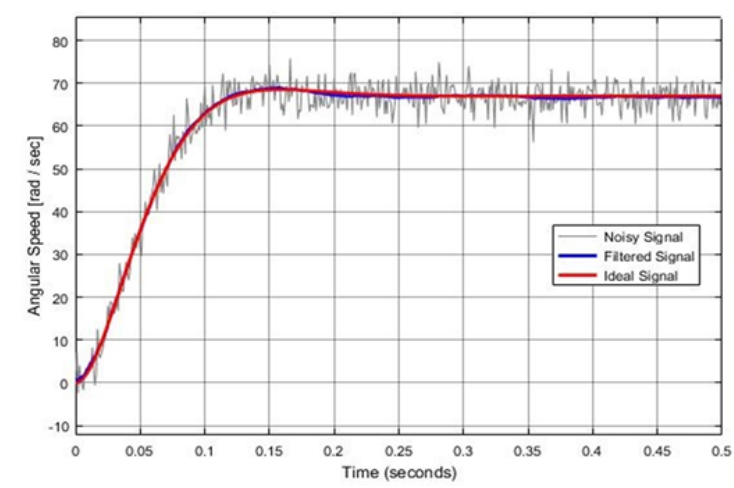

Gambar. 24. Grafik uji coba Kalman Filter tanpa beban
Pada gambar 24 ditunjukkan 3 buah grafik, dimana warna abu-abu menyatakan noise, warna merah adalah nilai kecepatan putar yang ideal, dan warna biru adalah hasil sinyal yang telah difilter menggunakan teknik Kalman Filter. Pada tabel III ditunjukkan hasil pengamatan tingkat keakurasian pada beberapa sampel pembacaan kecepatan motor DC berdasarkan gambar 24.

TABEL III

Hasil Pengamatan KaLMan FiLter TANPA BeBan

\begin{tabular}{cccccc}
\hline \hline No & $\begin{array}{c}\text { Waktu } \\
{[\text { detik] }}\end{array}$ & $\begin{array}{c}\text { Sinyal } \\
\text { Ideal } \\
{[\mathbf{r a d} / \mathbf{s e c}]}\end{array}$ & $\begin{array}{c}\text { Sinyal } \\
\text { Noise } \\
{[\mathbf{r a d} / \mathbf{s e c}]}\end{array}$ & $\begin{array}{c}\text { Moving } \\
\text { Average } \\
\text { Filter } \\
{[\mathbf{r a d} / \mathbf{s e c}]}\end{array}$ & $\begin{array}{c}\text { Error } \\
{[\mathbf{r a d} / \mathbf{s e c}]}\end{array}$ \\
\hline 1 & 0.001 & 0.03 & 7.19 & 0.83 & 0.8 \\
2 & 0.025 & 13.52 & 18.00 & 13.53 & 0.01 \\
3 & 0.050 & 35.58 & 30.67 & 35.53 & 0.05 \\
4 & 0.100 & 62.78 & 69.34 & 63.08 & 0.3 \\
5 & 0.150 & 68.48 & 74.37 & 68.86 & 0.38 \\
6 & 0.200 & 67.89 & 71.16 & 67.26 & 0.63 \\
7 & 0.250 & 67.18 & 66.09 & 66.70 & 0.48 \\
8 & 0.300 & 67.00 & 65.26 & 67.03 & 0.03 \\
9 & 0.400 & 67.02 & 67.26 & 66.68 & 0.34 \\
10 & 0.500 & 67.03 & 70.73 & 66.73 & 0.3 \\
\hline \hline
\end{tabular}

Pada gambar 25 ditunjukkan tingkat keakurasian teknik Kalman Filter terhadap waktu tanpa beban berdasarkan tabel III.

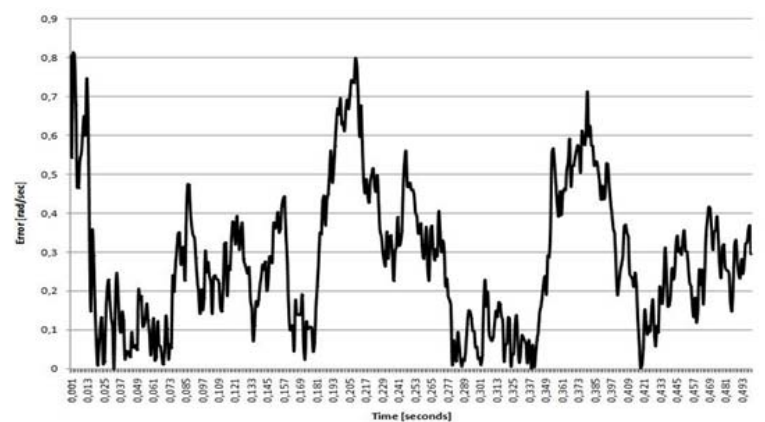

Gambar. 25. Grafik akurasi Kalman Filter terhadap waktu tanpa beban

Untuk mendapatkan respon dari teknik Kalman Filter dengan perubahan beban dari $\mathrm{TL}=0 \mathrm{Nm}$ ke $\mathrm{TL}=28.5 \mathrm{Nm}$ secara tiba-tiba dapat dilakukan dengan memberikan input berupa tegangan $\mathrm{Vt}=120 \mathrm{~V}$ dan torsi beban yang ingin disimulasikan ke dalam Plant. Gambar 26 adalah respon kecepatan motor DC dengan menggunakan teknik Kalman Filter akibat terjadinya perubahan beban pada saat $\mathrm{t}=0.5$ detik dengan tTotal $=1$ detik.

Pada gambar 26 ditunjukkan 3 buah grafik, dimana warna abu-abu menyatakan noise, warna merah adalah nilai kecepatan putar yang ideal, dan warna biru adalah hasil sinyal yang telah difilter menggunakan teknik Kalman Filter. Pada tabel IV ditunjukkan hasil pengamatan tingkat keakurasian pada beberapa sampel pembacaan kecepatan motor DC berdasarkan gambar 26. 


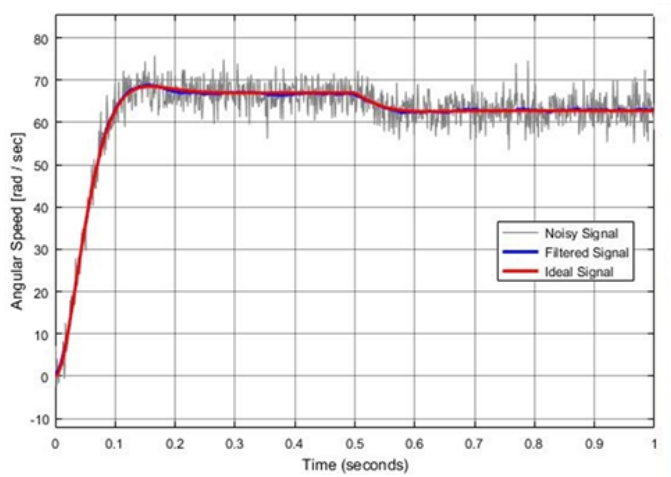

Gambar. 26. Grafik uji coba Kalman Filter dengan perubahan beban

TABEL IV

Hasil Pengamatan Kalman Filter dengan Perubahan Beban

\begin{tabular}{cccccc}
\hline \hline No & $\begin{array}{c}\text { Waktu } \\
{[\text { detik] }}\end{array}$ & $\begin{array}{c}\text { Sinyal } \\
\text { Ideal } \\
{[\mathbf{r a d} / \mathbf{s e c}]}\end{array}$ & $\begin{array}{c}\text { Sinyal } \\
\text { Noise } \\
{[\mathbf{r a d} / \mathbf{s e c}]}\end{array}$ & $\begin{array}{c}\text { Moving } \\
\text { Average } \\
\text { Filter } \\
{[\mathbf{r a d} / \mathbf{s e c}]}\end{array}$ & $\begin{array}{c}\text { Error } \\
{[\mathbf{r a d} / \mathbf{s e c}]}\end{array}$ \\
\hline 1 & 0.400 & 67.02 & 67.26 & 66.68 & 0.34 \\
2 & 0.500 & 67.03 & 70.73 & 66.65 & 0.38 \\
3 & 0.550 & 63.67 & 62.98 & 63.42 & 0.25 \\
4 & 0.600 & 62.67 & 62.62 & 62.43 & 0.24 \\
5 & 0.650 & 62.65 & 58.72 & 62.31 & 0.34 \\
6 & 0.700 & 62.73 & 67.31 & 63.15 & 0.42 \\
7 & 0.750 & 62.76 & 60.49 & 62.88 & 0.12 \\
8 & 0.800 & 62.76 & 64.79 & 62.97 & 0.21 \\
9 & 0.900 & 62.76 & 61.98 & 62.93 & 0.17 \\
10 & 1.000 & 62.76 & 64.51 & 62.95 & 0.19 \\
\hline \hline
\end{tabular}

Pada gambar 27 ditunjukkan tingkat keakurasian teknik Kalman Filter terhadap waktu dengan perubahan beban berdasarkan tabel IV.

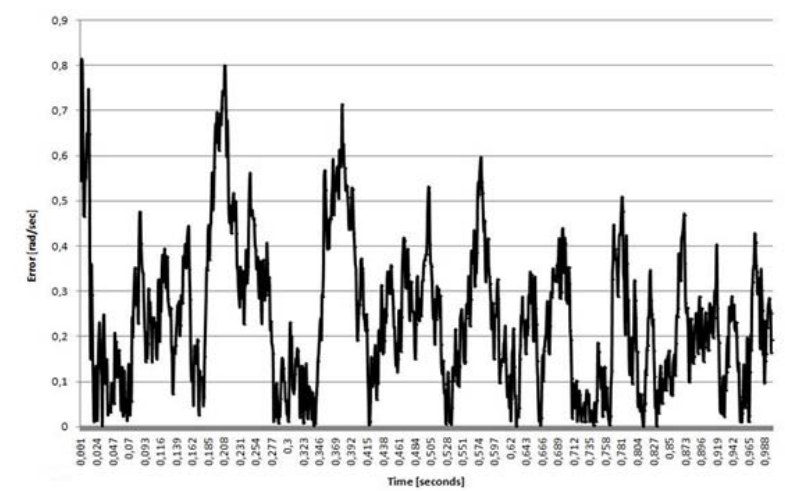

Gambar. 27. Grafik akurasi Kalman Filter terhadap waktu dengan perubahan beban

Sebuah indikator terbaik, bahwa Kalman Filter telah bekerja dengan optimal adalah dengan mengamati besarnya varian. Gambar 28 adalah grafik yang menunjukkan besarnya varian dan Kalman Gain dengan tTotal 0.5 detik.

Pada tabel V ditunjukkan hasil pengamatan varian dan Kalman Gain berdasarkan gambar 28.

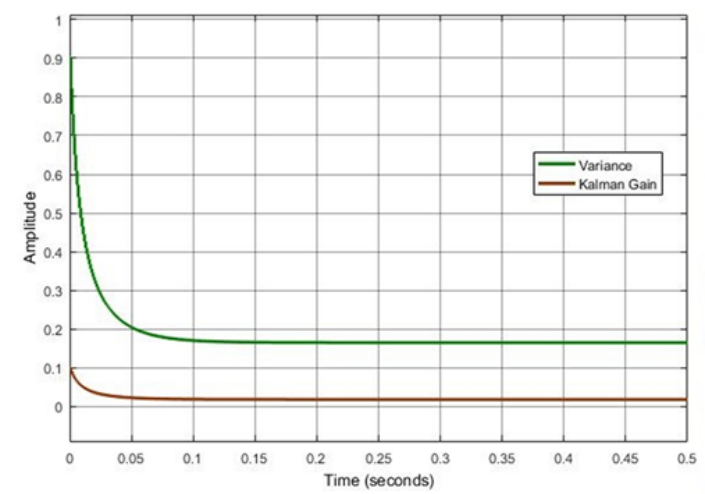

Gambar. 28. Grafik varian dan Kalman Gain

TABEL V

HASIL PENGAMATAN VARIAN DAN KALMAN GAIN

\begin{tabular}{cccc}
\hline \hline No & $\begin{array}{l}\text { Waktu } \\
\text { [detik] }\end{array}$ & Varian & Kalman Gain \\
\hline 1 & 0.001 & 0.8217 & 0.09130 \\
2 & 0.025 & 0.2880 & 0.03200 \\
3 & 0.050 & 0.2041 & 0.02268 \\
4 & 0.100 & 0.1705 & 0.01895 \\
5 & 0.500 & 0.1652 & 0.01836 \\
\hline \hline
\end{tabular}

\section{KESIMPULAN}

Kesimpulan-kesimpulan yang didapatkan adalah sebagai berikut:

1. Berdasarkan tabel I, hasil pemfilteran dengan menggunakan teknik Moving Average Filter mampu untuk mendekati nilai kecepatan yang sebenarnya dari sistem, dimana besarnya error dapat direduksi hingga kurang dari $0.5 \mathrm{rad} / \mathrm{sec}$ dalam waktu 6 detik. Jika dilihat tabel II, suatu perubahan terhadap sistem secara tiba-tiba dapat mengakibatkan peningkatan error.

2. Dengan menggunakan teknik Kalman Filter berdasarkan tabel III, dapat terlihat bahwa hasil estimasi mampu untuk memprediksi nilai kecepatan putar yang sebenarnya dari sistem, dimana besarnya error dapat direduksi hingga $0.5 \mathrm{rad} / \mathrm{sec}$ hanya dalam waktu 0.025 detik. Berdasarkan tabel IV, pada perubahan beban secara tiba-tiba terhadap sistem tidak terjadi peningkatan error yang berarti terhadap hasil estimasi.

\section{DAFTAR PUSTAKA}

[1] Abut, T., 2016, Modeling And Optimal Control Of A DC Motor, International Journal Of Engineering Trends And Technology, Vol. 32, No. 3, Turkey : Mus Alparslan University.

[2] Aji, S., 2001, Studi Analisa Dan Desain Kontroller Digital Untuk Pengaturan Kecepatan Motor DC, Indonesia : Sekolah Tinggi Teknik Surabaya.

[3] Al-Odienat, AI., Al-Mbaideen, A., 2015, Optimal Length Determination Of The Moving Average Filter For Power System Application, International Journal Of Innovative Computing, Information, And Control, Vol. 6, No. 2, Jordan : Mutah University.

[4] Ananthasayanam, MR., 2018, Tuning Of The Kalman Filter Using Constant Gain, India : Indian Institute Of Science

[5] Brown, RG., Hwang, PYC., 1997, Introduction To Random Signals And Applied Kalman Filtering, Edisi ketiga, United States Of America : John Wiley \& Sons, Inc.

[6] Faragher, R., 2012, Understanding The Basis Of The Kalman Filter Via A Simple And Intuitive Derivation, IEEE Signal Processing Magazine. 
[7] Larassati, D., Sirenden, BH., Qiyaman, D., Perbandingan Kalman Filter Dan Moving Average Pada Sistem Data Akusisi Pengukuran Suhu, Indonesia : Puslit Metrologi LIPI.

[8] Lu, Y., 2006, Clock Steering System Making Use Of GPS Time Transfer, Munich : Technische Universitat Munchen

[9] Ma, L., Wang, H., Chen, J., 2010, Analysis Of Kalman Filter With Correlated Noise Under Different Dependence, Journal Of Information \& Computational Science, Vol. 7, No. 5, China : Xidian University.

[10] Pateriya, U., Srivastava, A., Singh, R., Singh, BV., 2015, A Review On Noise Reduction Of Brushed DC Motor, International Journal Of Recent Scientific Research, Vol. 6, Issue 5, India : GB Pant University Of Agriculture \& Technology.

[11] Rautela, K., Bhakuni, AS., Sunori, S., 2017, Continuous Time State Space Model Of DC Motor Using Kalman Filter, International Journal On Emerging Technologies, India : Department Of ECE.

[12] Rhudy, MB., Salguero, RA., Holappa, K., 2017, A Kalman Filtering Tutorial For Undergraduate Students, International Journal Of Computer Science \& Engineering Survey, Vol. 8, No. 1, United States Of America : Pennsylvania State University.

[13] Shadkam, M., Mojallali, H., Member IACSIT, Bostani, Y., 2013, Speed Control Of DC Motor Using Extended Kalman Filter Based Fuzzy PID, International Journal Of Information And Electronics Engineering, Vol. 3, No. 1.

[14] Stallings, WM., Gillmore, GM., 1971, A Note On "Accuracy" And "Precision", Journal Of Educational Measurement, Vol. 8, No. 2, Illinois : University Of Illinois.

[15] Tanizaki, H., 1993, Kalman Filter Model With Qualitative Dependent Variables, The Review Of Economics And Statistics, Vol. 75, Issue 4, United States Of America : MIT Press.

Ivan Sutresno Hadi Sujoto lahir di Denpasar, Bali, pada tahun 1989. Dia menyelesaikan studi S1 di program studi Teknik Elektro iSTTS pada tahun 2019. Minat penelitiannya adalah bidang matematika, elektronika mikro dan analisa sinyal. 